\title{
Sedimentary changes vs. climate signals in bivalve shell and bulk rock compositions in a Late Pleistocene to Early Holocene fluvial section at Körösladány, SE-Hungary
}

\author{
Attila Demény \\ Gabriella Schöll-Barna \\ Institute for Geochemical Research \\ Hungarian Academy of Sciences, Budapest
}

\author{
Pál Sümegi \\ Department of Geology and Paleontology \\ University of Szeged, Szeged
}

Péter Sipos, Brigitta Réka Balázs

Institute for Geochemical Research, Hungarian Academy of Sciences, Budapest

\begin{abstract}
In this paper we present sedimentological and geochemical data for a section of fluvial deposits from SE Hungary covering the period of 25 to $5 \mathrm{ky}$ BP. Major and trace element geochemistry of bulk sediments as well as stable $\mathrm{C}$ and $\mathrm{O}$ isotope compositions of the carbonate content indicate significant changes in depositional facies and/or sediment provenance. Correlations of mineralogical and geochemical compositions were used to determine the stable isotope compositions of authigenic calcite component. Additionally, $\mathrm{C}$ and $\mathrm{O}$ isotope compositions of Unio crassus shell fragments were analysed that show a good agreement with climate change. Major climate change events within the studied time period were detected both in the shells and the authigenic calcite's compositions.
\end{abstract}

Key words: Pleistocene-Holocene transition, stable isotopes, geochemistry, fluvial sediments,

Unio crassus

An about $5 \mathrm{~m}$ thick fluvial section was studied in this work to detect climate signals during the latest Pleistocene and early Holocene. Based on three conventional ${ }^{14} \mathrm{C}$ age dates the section covers the period of $\sim 25$ to $5 \mathrm{ky} \mathrm{BP}$ and was formed at constant deposition rate. The 5.2 meter sediment profile was cleaned and collected for palaeontological, geological and geochemical analyses in the clay quarry which is located at the edge of the village of Körösladány in SE part of the Great Hungarian Plain (Hungary). According to the sedimentological, geomorphologic and geofaciological investigations the analysed profile consists of the sediment series of a filled up point bar channel which formed during the last phase of the Ice Age. 
The bottom of the profile $(5.2-4.5 \mathrm{~m})$ yielded medium sandy fine sands with a significant fraction of course-grained sands implying a deposition from highenergy fluvial waters. These sediments correspond to the active point bar channel deposits of a former meandering river. In this sandy layer there is a mass of shells of the mussel Unio crassus, preferring moving water habitats corroborated our first conception of the prevailing palaeoenvironmental conditions. The structure of this sand-rich layer was cross-bedding. The deposition of very fine-fine sands continued in the section between the depths of 4.5-2.5 $\mathrm{m}$ with the intercalation of minor silty seams and layers providing some Unio mussels suitable for analyses. The differential deposition of the sedimentary layers containing alternatively more sand or silt in the active riverbed must have been linked to the fluctuations of the water level in the channel. All these sediment layers show a fine wavy laminated structure. The relative high course silt sediment content show a possible deposition within Late Pleniglacial dust accumulation process.

At about 2.5 meters, the clay content increases in the sediment profile and the sand content decreases drastically parallel with this change, then at about 2.0 meters the organic matter content increase suddenly. The sedimentological changes suggest that the depositional environment and the climate might change strongly when this part of the analysed profile accumulated. According to the increasing clay and organic material content the temperature and weathering degree increased. Some fragments of Unio mussel can be found in this very fine parallel laminated clayey silt layer. From 2 meters up to the surface the content of the organic matter and clay increase gradually. The sediment structure and content suggest that the terminal phase of the filling process developed in this phase and alluvial sedimentation started around the analysed profile. Sporadic mussel shells can be found in this organic and clay-rich alluvial sediment. Some terrestrial warmth-loving molluscs, such as Cepaea vindobonensis, Chondrula tridens, Granaria frumentum suggest that this alluvial sedimentation developed already in the postglacial phase, during the Early Holocene.

Bulk sediments were analysed by means of XRF technique in order to determine major and trace element concentrations. Mineralogical compositions were determined by conventional semiquantitative XRD analyses. Stable $C$ and $\mathrm{O}$ isotope analyses were conducted on the carbonate fraction of the bulk sediment using conventional off-line preparation and dual inlet mass spectrometer. Fragments (usually $2-3 \mathrm{~cm}$ in size) of Unio crassus shells were collected from the sediments at $20-25 \mathrm{~cm}$ increments, then the preservation of their original aragonite structure was checked by cathodoluminescence microscopy. The fragments were sampled by at drilling three spots, the $\mathrm{C}$ and $\mathrm{O}$ isotope compositions of carbonate powders were determined using a continuous flow mass spectrometer equipped with an automated Gasbench device, then the results were averaged for each shell. 
As usual for fluvial deposits, the studied sediments are dominated by quartz (54-68 wt\%) and plagioclase (8-20 wt\%), while phillosilicates, feldspars, chlorite and carbonates are generally below $10 \mathrm{wt} \%$. The calcite content rises between 300 and $375 \mathrm{~cm}$ to $10-13 \mathrm{wt} \%$ with a concomitant increase of dolomite (5-9 wt\%). The samples contained no aragonite. This is partly due to the collection of large shell fragments from the sediment samples. Below $400 \mathrm{~cm}$, the carbonate amount is low with a relatively elevated calcite/dolomite ratio. The dolomite content suddenly increases at $375 \mathrm{~cm}$, and then it shows a constant decrease along with the calcite/dolomite ratio. The $\mathrm{SiO}_{2}$ content is slightly elevated below $400 \mathrm{~cm}(57$ to $69 \mathrm{wt} \%$ ) compared to the upper section part (52 to $62 \mathrm{wt} \%$ ). The $\mathrm{MgO}$ concentration is low below $400 \mathrm{~cm}$ (1.7 to $1.9 \mathrm{wt} \%)$, suddenly increases to $3.4 \mathrm{wt} \%$ at $375 \mathrm{~cm}$, then it decreases gradually to about $2.4 \mathrm{wt} \%$ in the uppermost part, with a significant positive $\mathrm{MgO}$-dolomite correlation $\left(\mathrm{R}^{2}=0.67\right)$. The $\mathrm{MnO}$ content shows again a difference between the lower $(=400 \mathrm{~cm})$ and the upper part of the section $(0.18-0.38$ and $0.10-0.17 \mathrm{wt} \%$, respectively). The $\mathrm{Sr}$ concentration of the bulk sediment is 160 to $180 \mathrm{ppm}$ below $400 \mathrm{~cm}$, then it decreases to about $120 \mathrm{ppm}$ up-section (Fig. 1A). The oxygen isotope composition of bulk sediment carbonate negatively correlates with the $\mathrm{Sr}$ content $\left(\mathrm{R}^{2}=0.85\right)$

Fig. 1

A. Stable oxygen isotope compositions of bulk carbonate (in $\%$ relative to V-PDB; filled circles) and $\mathrm{Sr}$ contents (in ppm; grey filled squares) of bulk sediment. B. Stable carbon and oxygen isotope compositions (in \%o relative to $\mathrm{V}$ $\mathrm{PDB})$ as a function of calcite content of bulk carbonate
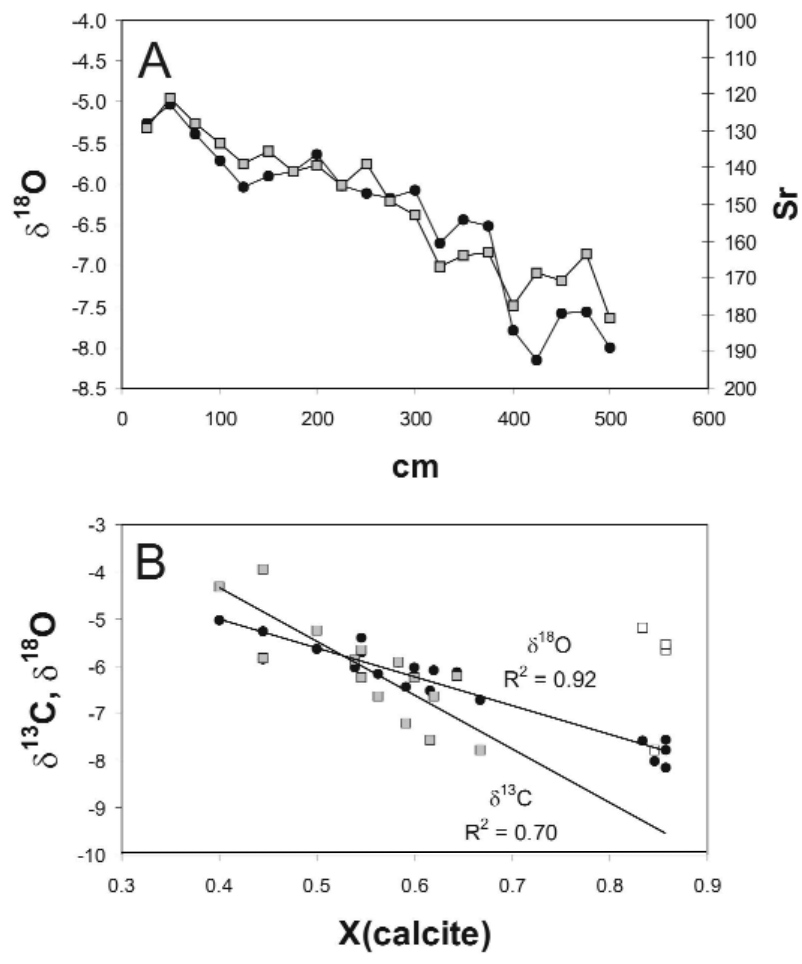

Central European Geology 54, 2011 
and shows a perfect negative correlation $\left(R^{2}=0.92\right)$ with the $X_{\text {calcite }}$ value (calcite/(calcite+dolomite)) (Fig. 1B). The bulk carbonate's carbon isotope compositions are negatively correlated with the carbonate content $\left(R^{2}=0.60\right)$, whereas the correlation with the $\mathrm{Sr}$ content is not that straightforward $\left(\mathrm{R}^{2}=0.28\right)$. The carbon isotope - $X_{\text {calcite }}$ negative correlation is significant only if the samples below $400 \mathrm{~cm}$ are excluded $\left(R^{2}=0.70\right)$ (Fig. 1B). The concentrations of other mineral components and elements show either random or rather complex patterns.

The carbon isotope compositions of bivalve shells are fluctuating between -14 and $-10 \%$, whereas the oxygen isotope values show a distinct pattern with $<-10 \%$ below $150 \mathrm{~cm}$ and a sudden increase to $-8.3 \%$ at $150 \mathrm{~cm}$.

Although it is well known that a major climate change with significant fluctuations occurred in the last $25 \mathrm{ky}$, the variations in mineralogical and chemical compositions indicate changes in deposition environment or denudation source as well. This is supported by the observation that the bulk carbonate's isotopic compositions (that may depend on the amount and origin of detrital carbonate) show no agreements with the shell data (that may depend more on climate).

Between 20 and $25 \mathrm{ky}$ the composition of the sediment was different from that of the subsequent period with higher amount of quartz, lower amount of dolomite and a calcite domination in the bulk carbonate. The good relationships between the bulk carbonate's isotopic compositions and the mineralogical and chemical compositions suggest mixing of different components. These relationships show that the denudation was dominated by limestones before 20 $\mathrm{ky}$ then a dolomitic terrain started to be eroded afterwards with some calcitic components in the sediments.

Opposite to the bulk carbonate compositions, the shells' oxygen isotope values show a clear relationship with climate. Although the fluctuations between 12 and $25 \mathrm{ky}$ do not significantly appear in the isotope values, the Pleistocene-Holocene transition is well displayed (Fig. 2A). This indicates that the bivalve shell data can reflect climate conditions in this fluvial environment.

Using the correlations with $X_{\text {calcite }}$ values, the isotopic compositions of the calcite component in the bulk carbonate can be calculated. Apart from the lower part of the section $(=20 \mathrm{ky})$ that shows relatively high $\delta^{13} \mathrm{C}$ values (Fig. $\left.2 \mathrm{~B}\right)$, the $\mathrm{C}$ and $\mathrm{O}$ isotope compositions of the calcite component resemble those of the shell fragments. Interestingly, the calculated compositions seem to reflect climate variations, correlating with the shell compositions (Fig. 2A-B).

Based on these data we can conclude that the stable isotope compositions of bulk sediment carbonate and bivalve shell data can be used as proxies of climate conditions, but facies and sediment source changes should also be taken into account before drawing a conclusion.

This study was financially supported by the Hungarian Scientific Research Fund (OTKA K-68343). 

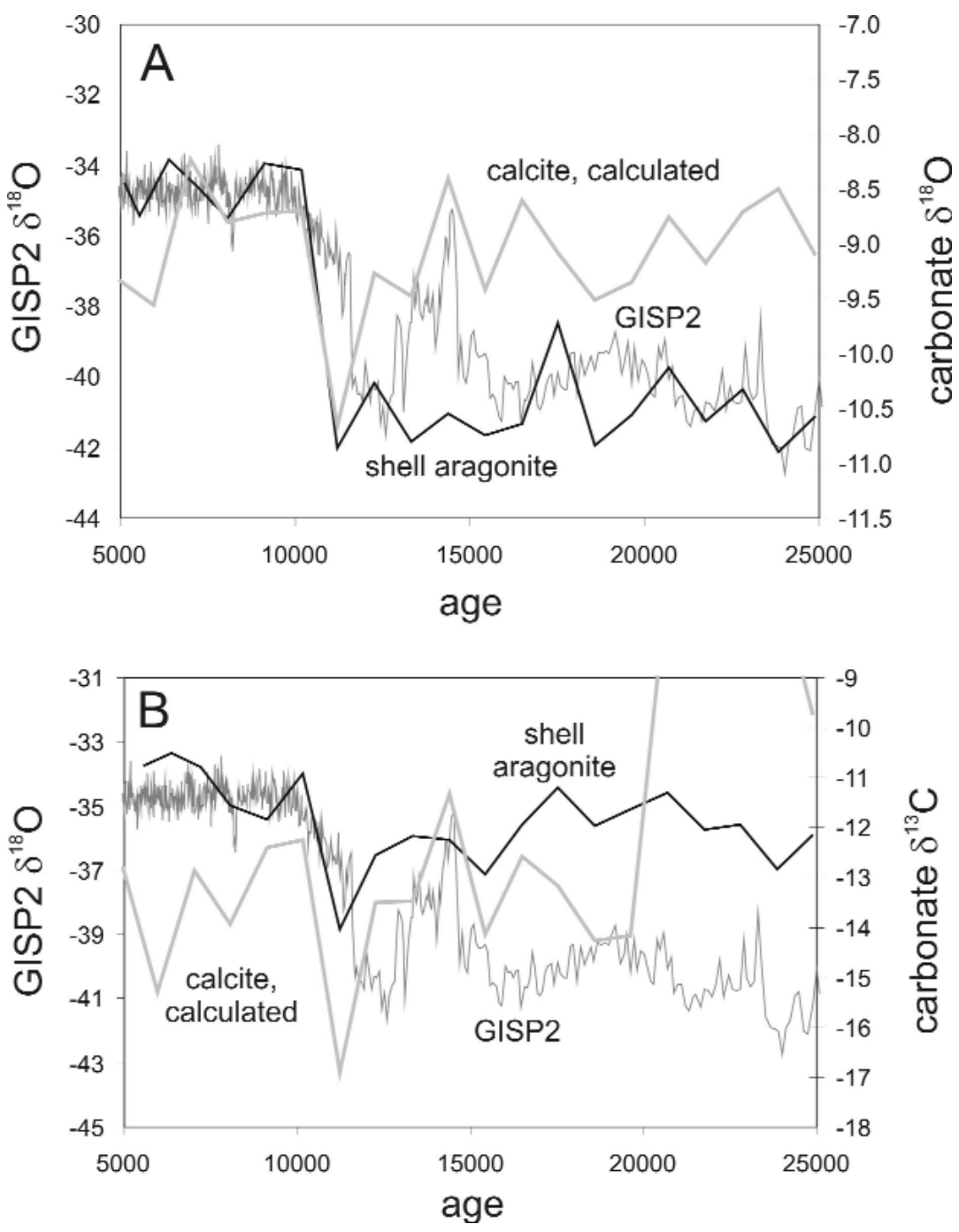

Fig. 2

Stable oxygen isotope compositions (in \%o relative to V-SMOW) of the GISP2 ice core (source: $\mathrm{ftp}: / / \mathrm{ftp}$.ncdc.noaa.gov) and stable oxygen (A) and carbon (B) isotope compositions of carbonates (aragonitic shells and calculated authigenic calcite component) 